\title{
PENGEMBANGAN METODE PENGKAYAAN UNTUK DETEKSI SEL Listeria monocytogenes RUSAK SUBLETAL
}

\author{
THE ENRICHMENT METHODE DEVELOPMENT FOR DETECTION OF \\ SUB LETHALLY DEMAGE CELL Listeria monocytogenes
}

Suharyono A.S.

Dosen Jurusan Teknologi Hasil Pertanian Fakultas Pertanian Universitas Lampung, J1. Sumantri Brojonegoro No. 1 Bandar Lampung 35145

\begin{abstract}
Listeria monocytogenes is a dangerous pathogen bacteria that can be spread by food. Food contamination by Listeria monocytogenes in Indonesia has not been much reported, however, research on this bacteria need to be started. The general objectives of this research were to develop the detection method and to observe the damaged cell of Listeria monocytogenes resulted from freezing process of shrimp. The media which were used for enrichment were FDA media (LEB) with the addition of goat blood, full milk, meat extract, or shrimp extract respectively. Sub lethally damage and lethal cells were detected by pour plate method. The results of the research showed that heating at $60^{\circ} \mathrm{C}$ for 10 minutes resulted in $98.75 \%$ damaged cells, $0.5 \%$ lethal cell and recovery time of sub lethally damaged cells was 8 hours at $37^{\circ} \mathrm{C} . F D A(L E B)+2 \%(b / v)$ full milk was the best media for recovering of Listeria monocytogenes (100\% recovery), FDA (LEB) $+2 \%(b / v)$ goat blood has showed the lowest influence of $4.34 \%$ recovery at 8 hours incubation time.
\end{abstract}

Keywords : detection method, frozen shrimp, Listeria monocytogenes, sub lethally damaged

ABSTRAK

Listeria monocytogenes adalah bakteri patogen berbahaya yang dapat disebarkan melalui makanan. Kontaminasi makanan oleh Listeria monocytogenes di Indonesia belum banyak dilaporkan walaupun penelitian mengenai bakteri ini perlu diawali. Tujuan penelitian secara umum adalah untuk mengembangkan metode deteksi dan untuk mengobservasi kerusakan sel Listeria monocytogenes yang dihasilkan dari proses pembekuan udang. Media yang digunakan untuk pengkayaan adalah media FDA (LEB) dengan penambahan masing-masing darah kambing, susu penuh, ekstrak daging atau ekstrak udang. Kerusakan sel secara subletal dan letal dideteksi dengan metode pour plate. Hasil penelitian menunjukkan bahwa pemanasan pada $60^{\circ} \mathrm{C}$ selama 10 menit menyebabkan kerusakan sel sebesar $98,75 \%$, sel letal $0,5 \%$ dan waktu penyembuhan sel rusak subletal adalah 8 jam pada $37^{\circ} \mathrm{C}$. FDA (LEB) $+2 \%(\mathrm{~b} / \mathrm{v})$ susu penuh adalah media terbaik untuk penyembuhan Listeria monocytogenes (penyembuhan 100\%), FDA (LEB) $+2 \%(\mathrm{~b} / \mathrm{v})$ darah kambing menunjukkan pengaruh terendah pada penyembuhan $4,34 \%$ dengan waktu inkubasi 8 jam.

Kata kunci : Listeria monocytogenes, kerusakan sel subletal, metode deteksi, udang beku

\section{PENDAHULUAN}

Beberapa tahun terakhir ini Listeria monocytogenes menuntut perhatian khusus dari industri pangan, yaitu sejak diketahui bakteri patogen berbahaya ini dapat disebarkan melalui makanan. Bakteri ini menyebabkan gejala listeriosis yang meliputi gejala meningoensefalitis, pneumonia, endokarditis, uretritis dan aborsi (ElShenawy dan Marth, 1988).

L. monocytogenes merupakan bakteri yang tersebar luas di alam dan dapat masuk ke dalam tubuh manusia melalui berbagai macam makanan seperti daging, unggas, ikan dan produksi hasil laut lainnya, susu, dan sayur-sayuran. Bakteri ini mempunyai kisaran suhu pertumbuhan $0.4-50^{\circ} \mathrm{C}$ (Arntzen dan Isaacson, 1992), oleh karena itu masih dapat tumbuh pada suhu pendingin makanan. Selain itu beberapa laporan menunjukkan bahwa bakteri ini masih ditemukan pada makanan/minuman yang telah dipateurisasi, serta masih dapat hidup pada medium dengan kadar garam $\mathrm{NaCl}$ sebesar 10\% (Shahamad et al., 1980; Doyle, 1988).

Beberapa metode pengujian Listeria monocytogenes yang telah dikembangkan (Lee dan McClain, 1986; Lovett et al., 1987) dianggap belum cukup sensitif, dan pada umumnya belum dapat mendeteksi sel bakteri yang telah mengalami kerusakan subletal akibat proses pengolahan makanan. 
Sel-sel yang mengalami kerusakan subletal umumnya tidak dapat tumbuh pada medium seleksi karena adanya senyawasenyawa selektif yang bersifat menghambat. Hal ini menyulitkan dalam penghitungan kuantitatif dalam uji mikrobiologi. Oleh karena itu, perlu dikembangkan medium dan kondisi khusus sehingga keberadaan bakteri yang rusak tetapi masih hidup tersebut dapat dideteksi di dalam makanan.

Pengaruh berbagai tahap proses pengolahan terhadap kerusakan Listeria monocytogenes, baik letal maupun subletal, juga perlu dipelajari sehingga pengendalian keamanan makanan melalui proses pengolahan juga mencakup pengendalian terhadap bakteri ini. Sebagai model proses digunakan tahap proses pembekuan udang, karena udang merupakan makanan yang berisiko tinggi tercemar Listeria monocytogenes. Udang merupakan produk ekspor yang potensial sedangkan beberapa negara seperti Amerika Serikat sudah mensyaratkan "Bebas Listeria" bagi produkproduk yang mereka impor (Anonim, 1992). Ekspor udang asal negara Pakistan, India, dan Indonesia ditolak oleh negara Amerika karena produk ekspor tersebut positif terhadap uji Listeria monocytogenes (Faber dan Daley, 1994). Kasus yang sama juga dilakukan oleh negara Jepang terhadap produk ekspor udang dari negara Pakistan, India, Indonesia, dan Srilanka (Fu, et al., 1995).

Metode deteksi yang telah dikembangkan umumnya hanya dapat mendeteksi sel-sel L. monocytogenes yang normal pada makanan, tetapi tidak sensitif untuk dapat mendeteksi sel-sel yang belum mati tetapi mengalami kerusakan subletal akibat proses pengolahan, padahal sel semacam ini dapat tumbuh dan berkembang biak di dalam makanan. Tidak terdeteksinya sel-sel yang mengalami kerusakan subletal dapat mengakibatkan diperolehnya hasil uji negatif yang salah.

Penelitian yang dilaksanakan bertujuan untuk: (1) mengetahui pengaruh jenis media dan kondisi proses penyembuhan terhadap sel Listeria monocytogenes yang mengalami kerusakan subletal, (2) mengembangkan metode deteksi yang sensitif terhadap L. monocytogenes pada makanan khususnya udang beku, terutama untuk mendeteksi sel-sel yang mengalami rusak subletal akibat proses pengolahan.

\section{BAHAN DAN METODE}

\section{Bahan}

Bahan yang digunakan adalah udang segar yang berasal dari Tempat Pelelangan Ikan (TPI) Jakarta Utara, kultur murni Listeria monocytogenes Scott A dari Balai Penelitian Veteriner (Balitvet) Cimanggu Bogor, dan darah kambing. Bahan kimia yang digunakan antara lain glukosa, $\mathrm{K}_{2} \mathrm{HPO}_{4}$, polimiksin $\mathrm{B}$, akriflavin $\mathrm{HCl}$, asam nalidikat, air suling, $\mathrm{NaCl}$, larutan hipoklorin, dan lainlain.

\section{Metode}

Penelitian dilakukan dalam dua tahap, penelitian tahap pertama dilakukan untuk menentukan tingkat kerusakan subletal sel L. monocytogenes pada suhu $60^{\circ} \mathrm{C}$ selama 10 menit (Whiting dan Masana, 1994). Penelitian tahap kedua dilakukan untuk menentukan waktu optimal penyembuhan sel L. monocytogenes serta pengaruh formulasi media terhadap penyembahan sel L. monocytogenes yang mengalami kerusakan subletal.

\section{Persiapan inokulum}

Inokulum diambil dari kultur beku L. monocytogenes Scott A yang diperoleh dari Balai Penelitian Vetteriner (Balitvet), Cimanggu Bogor. Pemulihan dilakukan menurut metode FDA (1994), yaitu $1 \mathrm{ml}$ kultur tersebut diambil dan dilakukan pemupukan pada cawan dengan McBride Listeria Agar (MLA) secara duplo. Inkubasi dilakukan pada suhu $37^{\circ} \mathrm{C}$ selam 24 jam.

\section{Pembuatan suspensi L. Monocytogenes}

Dari MLA diambil sel kultur yang berumur 24 jam, kemudian disentrifus dengan kecepatan $2.500 \mathrm{rpm}$ selama 10 menit. Endapan dicuci sebanyak tiga kali dengan menggunakan air suling, kemudian dibuat suspensi sel dalam $1000 \mathrm{ml}$ bufer fosfat steril. 


\section{Persiapan sampel}

Unit sampel yang digunakan adalah udang yang telah dibersihkan menggunakan air suling, masing-masing $100 \mathrm{~g}$ untuk 1 unit sampel yang dikemas dalam plastik PE steril dan dilakukan secara aseptis.

\section{Inokulasi}

Setiap unit sempel dicelupkan dalam suspensi L. monocytogenes selam 10 menit, kemudian ditiriskan. Selanjutnya dimasukkan ke dalam kemasan plastik PE steril secara aseptis, ditutup rapat dan dibekukan atau sesuai dengan perlakuan selanjutnya.

\section{Pengaruh blansir terhadap kerusakan subletal Listeria monocytogenes}

Sebanyak 10 g udang bersih dicemari dengan suspensi L. monocytogenes, kemudian dicelupkan dalam air panas $60^{\circ} \mathrm{C}$ selama 10 menit. Selanjutnya diamati sel yang normal dan mengalami kerusakan subletal pada waktu tersebut.

Penentuan tingkat kerusakan subletal menggunakan cara yang dianjurkan oleh Whiting dan Masana (1994) dan FDA (1994). Contoh ditanam pada media Tryticase Soy Agar (TSA) sebagai medium nonselektif dan medium Listeria Selective Agar (LSA) sebagai medium selektif. Setelah diinkubasi selama 48 jam pada suhu $37^{\circ} \mathrm{C}$, jumlah koloni dihitung dan jumlah sel akan diketahui dengan mengalikan jumlah koloni dengan faktor pengeceran.

\section{Prosedur yang direkomendasi oleh FDA} (Tahap Enrichment)

Sebanyak 25 g contoh ditambahkan ke dalam $225 \mathrm{ml}$ enrichment medium yang per liter terdiri dari $30 \mathrm{~g}$ Triptycase Soy Broth, 6g ekstrak khamir, $15 \mathrm{~g}$ acryflafin $\mathrm{HCL}, 40 \mathrm{mg}$ asam nalidisat, dan $50 \mathrm{mg}$ siklohemisida. Setelah dihomogenisasi selama 2 menit, campuran diinkubasi pada suhu $37^{\circ} \mathrm{C}$ selama 24 jam (Lovett et al., 1987), setelah waktu inkubasi tersebut terhadap kultur dilakukan pemupukan dengan metode permukaan $(0,1 \mathrm{ml})$ langsung pada dua cawan (duplo) MLA.
Perlakuan Penyembuhan Listeria Monocytogenes yang mengaami kerusakan subletal

Kondisi pemanaan yang menghasilkan kerusakan subletal dan tidak terdeteksi dengan metode Lovett et al. (1987) seperti pada prosedur pengaruh blasir, dipilih untuk dilakukan pada proses penyebuhan. Cara penyembuhan yang dilakukan adalah:

(a) Sel yang telah mengalami kerusakan subletal dimasukkan ke dalam media FDA + darah kambing sebanyak 2,4 dan $6 \%$ (b/v) (Doyle dan Scoeni, 1986) di dalam tabung reaksi steril, dan diinkubasi pada suhu $37^{\circ} \mathrm{C}$ selama 24 jam.

(b) Sel yang telah mengalami kerusakan subletal dimasukkan ke dalam media FDA + ektrak daging $(1: 10)$ dalam air pepton $0,1 \%$ sebanyak 2,4 dan $6 \%(\mathrm{~b} / \mathrm{v})$ (Farber dan Daley, 1994) dalam tabung reaksi streil, dan diinkubasi pada suhu $37^{\circ} \mathrm{C}$ selama 24 jam.

(c) Sel yang telah mengalami kerusakan subletal dimasukkan ke dalam medai FDA + bubuk susu penuh sebanyak 2,4, dan 6\% (b/v) (Rocourt, 1994) di dalam tabung reaksi steril dan diinubasi pada suhu $37^{\circ} \mathrm{C}$ selam 24 jam.

(d) Sel yang telah mengalami kerusakan subletal dimasukkan ke dalam media FDA + ekstrak udang (1:10) sebanyak 2,4 dan 6\% (b/v) (Embarek, 1994) dalam tabung reaksi steril dan diinkubasi pada suhu $37^{\circ} \mathrm{C}$ selam 24 jam.

Sel yang mengalami proses penyembuhan diamaati menggunakan prosedur yang dinjurkan oleh Whiting dan Masana (1994).

Metode yang dipergunakan untuk menilai kerusakan dan kematian tersebut adalah metode perhitungan pada agar cawan yaitu dengan agar tuang. Data yang diperoleh dianalisis keragamannya untuk menilai pengaruh masing-masing perlakuan.

\section{Analisis kerusakan sel dengan Scanning Electrone Microscope (SEM).}

Kerusakan yang disebabkan oleh perlakuan yang memberikan pengaruh ekstrim terhadap kerusakan subletal sel L. monocytogenes, analisis sel dengan 
Tabel 1. Pengaruh Formulasi Media terhadap Log Jumlah Sel yang Mengalami Penyembuhan dengan LSR

\begin{tabular}{lcccc}
\hline \multirow{2}{*}{ Media Bahan } & $\begin{array}{c}\text { Media Jumlah } \\
(\mathbf{\%})\end{array}$ & Rata-rata & \multicolumn{2}{c}{ Perbedaan } \\
\cline { 4 - 5 } Darah Kambing & 2 & 5,62 & - & LSR 0,01 \\
& 4 & 5,74 & $\mathrm{~b}$ & $\mathrm{c}$ \\
\multirow{2}{*}{ Susu penuh } & 6 & 5,67 & $\mathrm{~b}$ & $\mathrm{c}$ \\
& 2 & 6,98 & $\mathrm{a}$ & $\mathrm{c}$ \\
\multirow{2}{*}{ Ekstrak daging } & 4 & 6,68 & $\mathrm{a}$ & $\mathrm{c}$ \\
& 6 & 6,60 & $\mathrm{a}$ & $\mathrm{c}$ \\
\multirow{2}{*}{ Ekstrak udang } & 2 & 6,49 & $\mathrm{a}$ & $\mathrm{c}$ \\
& 4 & 6,61 & $\mathrm{a}$ & $\mathrm{c}$ \\
& 6 & 6,72 & $\mathrm{a}$ & $\mathrm{c}$ \\
& 2 & 6,79 & $\mathrm{a}$ & $\mathrm{c}$ \\
& 4 & 6,76 & $\mathrm{a}$ & $\mathrm{c}$ \\
\hline
\end{tabular}

Keterangan: LSR = Least Significant Range

*) Hasil uji nilai tengah yang diikuti huruf yang sama tidak berbeda nyata, sedangkan perlakuan berbeda nyata jika diikuti huruf yang berbeda pada masing-masing nilai LSR.

Scanning Electrone Microscope (SEM), untuk melihat kerusakan yang terjadi. Prosedur yang digunakan adalah sebagai berikut (JEOL, 1995): suspensi sel murni yang telah diperlakukan disentrifus pada $3.000 \mathrm{rpm}$ selama 5 menit. Spesimen dicuci dengan buffer fosfat yang dipisahkan cairannya dengan sentrifus (2 kali), ditambahkan $2 \%$ glutaraldehid $(\mathrm{pH} \pm 7,3)$ dan didiamkan selama 2 jam, lalu disentrifus (3.000 rpm, selama 5 menit). Endapan dicuci dengan buffer fosfat, kemudian ditambahkan $50 \%$ etanol lalu dikocok dan disentrifus, kemudian filtrat dibuang, diulangi dengan etanol $60 \%$, 70\%, dan $80 \%$. Ditambahkan $100 \%$ isoamil asetat, lalu dikocok dan dibiarkan selama 10 menit. Diteteskan larutan sampel pada cover glass dan dikeringkan pada suhu udara ruang. Sampel tersebut diamati dengan SEM. Sebelumnya, terhadap sampel dilakukan proses coating menggunakan logam $\mathrm{Au}$ (emas) dengan ketebalan $10 \mathrm{~mA}^{0}$ selam 240 detik.

\section{HASIL DAN PEMBAHASAN}

Kerusakan subletal sel L. monocytogenes pada suhu $60^{\circ} \mathrm{C}$ selama 10 menit.

Berdasarkan perhitungan hasil percobaan diperoleh informasi bahwa pemanasan pada suhu $60^{\circ} \mathrm{C}$ selama 10 menit, tingkat kerusakan subletal sel monocytogenes adalah sebesar $98,75 \%$ sedangkan tingkat kematian sel tersebut sebesar $0,5 \%$. Proses pemanasan pada suhu $60^{\circ} \mathrm{C}$ selama 10 menit dianggap cukup efektif karena cukup mampu menyebabkan terjadinya kerusakan subletal sel L. monocytogenes hingga 98,75\%. Kerusakan ini melebihi tingkat kerusakan subletal sel L. monocytogenes yang dianggap baik yaitu lebih besar daripada $80 \%$, serta tingkat kematian $<2,5 \%$ (Whiting dan Masana, 1994).

Proses pemanasan pada suhu $60^{\circ} \mathrm{C}$ selama 10 menit ternyata juga tidak mengubah warna udang, sehingga udang dengan perlakuan ini masih memberikan penampakan warna yang segar. Kondisi pemanasan ini selanjutnya digunakan sebagai persiapan prapembekuan udang pada penelitian tahap kedua.

\section{Pengaruh formulasi media terhadap penyambuhan sel L. monocytogenes yang megalami kerusakan subletal}

Formulasi berpengaruh sangat nyata terhadap tingkat penyembuhan sel, sedangkan persentase suplemen tidak berpengaruh dan tidak terjadi interaksi antar keduanya. Perbandingan nilai tengah pengaruh formulasi media terhadap log jumlah sel yang mengalami penyembuhan dengan least significant range (LSR) dapat dilihat pada Tabel 1.

Hasil uji lanjutan nilai tengah dengan uji Duncan memperlihatkan bahwa pada LSR $=0,05$, formulasi media dengan darah 
kambing memberikan pengaruh yang berbeda nyata terhadap tingkat penyembuhan sel dibandingkan media dengan susu penuh, ekstrak daging, atau dengan ekstrak udang.

Formulasi perlakuan dengan darah kambing memberikan pengaruh yang berbeda nyata terhadap tingkat penyembuhan sel dibandingkan perlakuan dengan susu penuh, ekstrak daging, atau ekstrak udang. Tingkat penyembuhan sel L. monocytogenes yang mengalami kerusakan subletal pada berbagai perlakuan formulasi media setelah inkubasi 8 jam terlihat pada Tabel 2.

Perlakuan yang memberikan pengaruh terbaik terhadap tingkat penyembuhan subletal adalah formula dengan $2 \%$ (b/v) susu penuh dengan tingkat penyembuhan mencapai 104,9\%. Dibandingkan dengan darah kambing, ekstrak daging, dan ekstrak udang, susu penuh ternyata mempunyai nilai gizi yang terbaik.

Tabel 2. Persen Penyembuhan Sel L. Monocytogenes Dari Kerusakan Subletal Pada Berbagai Perlakuan Formulasi Media Setelah Inkubasi 8 Jam.

\begin{tabular}{ccc}
\hline $\begin{array}{c}\text { Perlakuan Formulasi } \\
\text { Media }\end{array}$ & $\begin{array}{c}\text { Tingkat penyembuhan sel } \\
\text { Listeria monocytogenes }(\%)\end{array}$ \\
\hline Media LEB (FDA) & & nar \\
$+2 \%(\mathrm{~b} / \mathrm{v})$ darah kambing & 4,34 & disa \\
$+4 \%(\mathrm{~b} / \mathrm{v})$ darah kambing & 5,57 & dila \\
$+6 \%(\mathrm{~b} / \mathrm{v})$ darah kambing & 4,75 & E \\
$+2 \%(\mathrm{~b} / \mathrm{v})$ Ekstrak daging & 31,57 & \\
$+4 \%(\mathrm{~b} / \mathrm{v})$ Ekstrak daging & 42,34 & \\
$+6 \%(\mathrm{~b} / \mathrm{v})$ Ekstrak daging & 61,31 & \\
$+2 \%(\mathrm{~b} / \mathrm{v})$ Ekstrak udang & 69,52 & \\
$+4 \%(\mathrm{~b} / \mathrm{v})$ Ekstrak udang & 73,62 & \\
$+6 \%(\mathrm{~b} / \mathrm{v})$ Ekstrak udang & 82,34 & \\
$+2 \%(\mathrm{~b} / \mathrm{v})$ susu penuh & 104,90 & \\
$+4 \%(\mathrm{~b} / \mathrm{v})$ susu penuh & 49,52 & \\
$+6 \%(\mathrm{~b} / \mathrm{v})$ susu penuh & 40,80 & \\
\hline
\end{tabular}

Komponen protein susu (kasein) yang mencapai 25\% diperlukan oleh sel Listeria monocytogenes yang mengalami kerusakan subletal untuk membangun kembali jaringan sel yang rusak akibat pemanasan. Hal ini karena selama pemanasan diduga terjadi perubahan makromolekul dari senyawa dasar yang dibangun dari senyawa protein seperti asam ribonukleat, ribosom, dan senyawa DNA.
Glass dan Doyle (1989), menyatakan bahwa akibat proses pemanasan sel Listeria monocytogenes akan mengalami perubahan makromolekul, misalnya asam ribonukleat, ribosoma dan DNA, dan memerlukan protein yang relatif tinggi dalam media penyembuhannya. Sedangkan Marth (1988), menginformasikan bahwa pada tahap penyembuhan sel L. monocytogenes memerlukan senyawa pepton dari kasein susu di samping senyawa pepton dari biji-bijian dalam jumlah yang relatif kecil.

\section{Analisis kerusakan sel dengan SEM}

Analisis kerusakan sel dilakukan terhadap perlakuan yang memberikan pengaruh ekstrim terhadap kerusakan subletal sel L. monocytogenes. Perlakuan yang memberikan pengaruh ekstrim terhadap kerusakan sel L. monocytogenes adalah pemanasan pada suhu $60^{\circ} \mathrm{C}$ selama 10 menit, pembekuan cepat pada suhu $-40^{\circ} \mathrm{C}$ selama 60 menit, perendaman dalam larutan garam 20\% (b/v) selama 10 menit, dan perendaman dengan larutan klorin 150 ppm selama 10 menit.

Analisis kerusakan sel menggunakan SEM belum menunjukkan hasil yang optimal, karena kerusakan pada permukaan sel tidak nampak dengan jelas. Dari analisis ini, disarankan bahwa untuk mengetahui kerusakan pada permukaan sel dapat dilakukan menggunakan TEM (Transmition Electrone Microscope). Gambar-gambar analisis sel menggunakan SEM dapat dilihat pada Gambar 1 sampai Gambar 3.

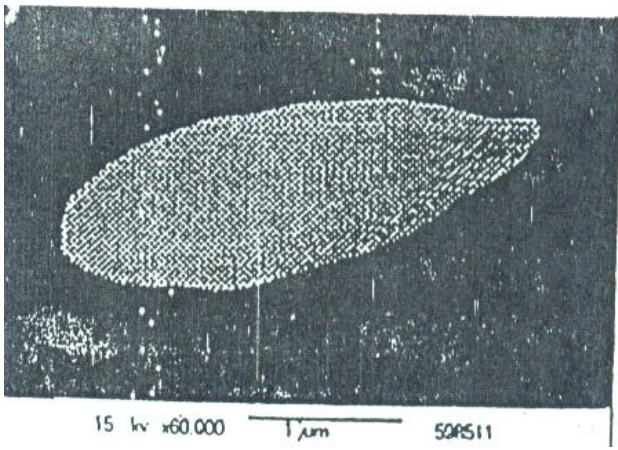

Gambar 1. Bentuk Sel L. Monocytogenes Tanpa Perlakuan (Kontrol). Pembesaran 60.000 Kali Menggunakan SEM 


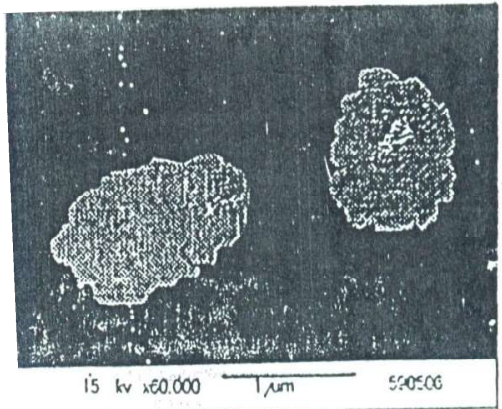

Gambar 2. Bentuk Sel L. Monocytogenes Setelah Pemanasan $60^{\circ} \mathrm{C}, 10$ Menit. Pembesaran $\quad 60.000 \quad$ Kali Menggunakan SEM
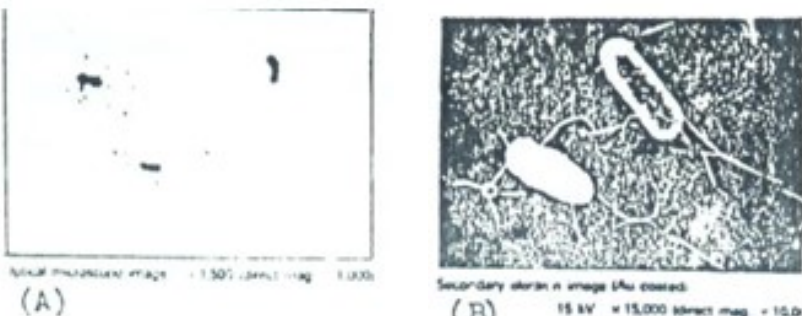

A

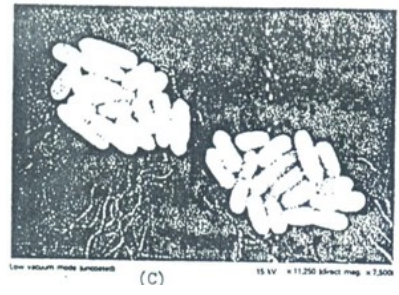

C

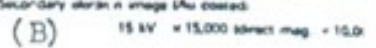

B

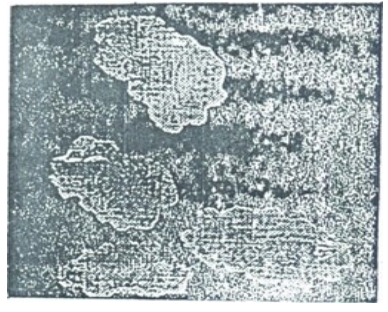

D

Gambar 3. Bentuk Sel L. Monocytogenes Tanpa Perlakuan Menggunakan Mikroskop Biasa (A), SEM Dan Pelapisan Emas (B), SEM Tanpa Pelapisan (C), Dan Setelah Perlakuan Perendaman Dalam Nacl 20\%, 10 Menit (D). Pembesaran $\quad 60.000 \quad$ Kali Menggunakan SEM.

\section{KESIMPULAN}

Dari hasil penelitian dan pembahasan di atas, maka dapat disimpulkan:

(1) Formulasi media FDA (LEB) $+2 \%(b / v)$ susu penuh adalah perlakuan yang terbaik, dengan tingkat penyembuhan kerusakan subletal sel Listeria monocytogenes mencapai $100 \%$ pada waktu inkubasi optimal 8 jam.

(2) Proses penyembuhan sel Listeria monocytogenes yang mengalami kerusakan subletal ternyata dapat

meningkatkan kepekaan metode deteksinya.

\section{DAFTAR PUSTAKA}

Anonim. 1992. Penolakan Ekspor Udang Indonesia ke Amerika. Warta Ekonomi. Edisi 6 Juli 1992. Jakarta.

Arntzen, L. and M. Isaacson. 1992. A Comparative Study of An ELISA and Bacterial Culture for The Detection of Listeria monocytogenes in Food. Proceedings 3rd Word Congress Foodborne Infections and Intoxications, Berlin, 16 - 19 Juni, 1992. Vol. I, pp. $547-550$.

Doyle, M.P. 1988. Effect of Environmental and Processing Conditions on Listeria monocytogenes. J. Food Technol. 42(4): $169-171$.

Doyle, M.P. and J.L. Schoeni. 1986. Listeria Infection. J. Appl. Environ Microbiol. 51:1127-1129.

El-Shenawy, M. And E.H. Marth. 1988. Inhibition and Inactivation of Listeria monocytogenes by Sorbic Acid. J. Food Protect. 51:842 - 847.

Embarek, P.K.B. 1994. Presense, Defection and Growth of Listeria monocytogenes in Seafoods. A Review. Int. J. Food Microbiol. 23:17-34.

Farber, J.M. and E. Daley. 1994. Presence and Growth of Listeria monocytogenes in Naturally Contaminated Meats. Int. J. Food Microbiol. 22:33 - 42.

Food and Drug Administration (FDA). 1994. Metode of Microbial Analysis. U.S. Government Printing Office, Washington D.C.

Fu, A.H., J.G. Sebranek, and F.A. Murano. 1995. Survival of Listeria Monocytogenes, Yersinia enterocolitica and Escherichia coli 0157:117 and Quality Changes After Irradiation of Beef Steaks and Ground Beef. J. Food Science. 60:972 - 977.

Glass, K.A. and M.P. Doyle. 1989. Fate and Thermal Inactivation of Listeria monocytogenes in Beaker Sausage 
and Pepperoni. J. Food Protection. 52:226 - 231

JEOL. 1995. Specimen Preparation Methods for Scanning Electron Microscopes. JEOL Application Note. Tokyo. 23 pp.Lee, W.H. and D. McClain. 1986. Improved Listeria monocytogenes Selective Agar. Appl. Environ Microbiol. 52:1215 - 1217 .

Lovett, J., D.W. Francis, and J.M. Hunt. 1987. Listeria monocytogenes in Raw Milk: Detection, Incidence and Pathogenicity. J. Food Protect. 50:188 - 191 .

Marth, E.H. 1988. Disease Characteristics of Listeria monocytogenes. J. Food Technol. 42(4):181 - 191.

Rocourt, J. 1994. Listeria monocytogenes. The State of Science, Dairy, Food, and Environmental Sanitation. 14(2): $70-80$.

Shahamad, M.A. Seaman, and M. Woodbine. 1980. Influence of Sosium Chloride, $\mathrm{pH}$, and Temperature on The Inhibitory Activity of Sosium Nitrite on Listeria monocytogenes. In G.W. Gould and J.E.L. Corry (ed.) Microbial Growth and Survival in Extremes of Environment. Academic Press, London. p. 227.

Whiting, R.C. and M.O. Masana. 1994. Listeria monocytogenes Survival Model Validated in Simulated Uncooked-Fermented Meat Products for Effects of Nitrite and pH. J. Food Sci. 59(4):760 - 766. 